\title{
CONGRESSOS E CONFERÊNCIAS \\ NO ESTRANGEIRO
}

Para informação adicional contactar a sede da S.P.Q., Av. da República, $37-4 .^{\circ}-1000$ Lisboa - Tel. 734637.

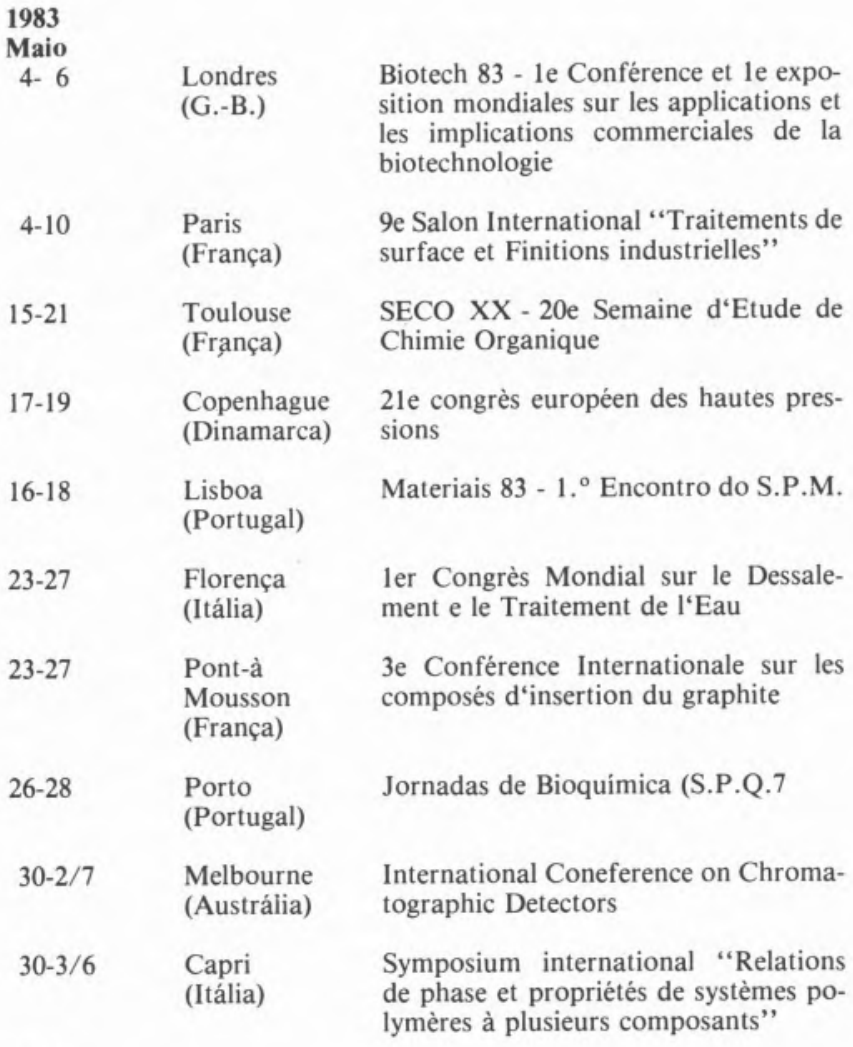

Junho

1- 3 Lucerne

(Suiça)

2-

$5-10$

6- 9

$6-10$

12-16

13-16

13-17

Berlim

(R.F.A.)

Cologne

(R.F.A.)

Midland

(MI, U.S.A.)

Birmingham

(G.-B.)

Stockholm

(Suécia)

\section{Londres}

(G.-B.)

Ystad

(Suécia)

Florença

(Itália)

Galway

(Irlanda)

5e Conférence Internationale "Progrès das la stabilisation et la dégradation contrôlée des polymères"

International Conference "Polymer Photochemistry",

29th International Congress of Pare and Applied Chemistry

Symposium "Milestones and Trends in Polymer Science: a tribute to Turner Alfrey",

International Chemical and Process Engineering Show and Conference-Eurochem 83

EUCHEM Conference: “High Resolution Electron Microscopy in Solid State Chemistry",

Corrosion of Reinforcement in Concret Construction

Euchem Conference on Synthetic Uses of Ring-Opening Rections of Aromatic Heterocycles

1st International Conference on Bioinorganic Chemistry

11-14

$\begin{array}{cl}\text { 16-18 } & \begin{array}{l}\text { Dublin } \\ \text { (Irlanda) }\end{array} \\ 21-23 & \begin{array}{l}\text { Stuttgart } \\ \text { (R.F.A.) }\end{array} \\ 27-29 & \begin{array}{l}\text { Londres } \\ \text { (G.-B.) }\end{array} \\ 29-1 / 7 & \begin{array}{l}\text { Londres } \\ \text { (G.-B.) }\end{array}\end{array}$

Junho

3- $8 \quad \begin{aligned} & \text { Amsterdam } \\ & \text { (Holanda) }\end{aligned}$

6- 9 Paris

(França)

10-15

Edimburgo (Escócia G.B.)

15th Conference of the European Group for Atomic Spectroscopy

2nd International Conference on Bounnal and asymptotic methods

2nd International Conference in Science and Technology of Zirconia-Zirconia 83

Industry Education Interactions at the Graduate and Senior Technician Level

Colloque: Fatigue dans les polymères

7th International Congress of Radiation Research

4th International Conference on Solic State Ionics

International Conference on the Chemistry of Chromium, Molybdenum and Tungsten

International Association of Biological Standardization of Monocional Antibodies: Standardization in their Production and Use

Praga

(U.R.S.S)

6th International Meeting on NMR Spectroscopy

11-15 Mayence

(R.F.A.)

11-15 Swansea

(G.-B.)

11-15 Athènes

(Grécia)

24th Microsymposium ou Macromolecules. "Copolymers: Structure and Solution Properties"

Edimburgo International Conference and Exhibi-

$7 e$ Conférence internationale sur les Origines de la vie

Praga

(U.R.S.S.)

Imeboron V-Organic and Inorganic

0e Conférence international sur la science et la technologie dans les revêtements organiques

Montreal

(Canadá)

Cambridge

(G.-B.)

Sherbrooke (Canadá) 